\title{
Cocoa byproduct in diets for dairy heifers
}

\section{Mércia Regina Pereira de Figueiredo ${ }^{1 *}$ (iD), Eloisa de Oliveira Simões Saliba ${ }^{2}$ iD, Geraldo Sérgio Senra Carneiro Barbosa ${ }^{3}$ (iD, Fernando César Ferraz Lopes ${ }^{4}$ (iD, Filipe Aguiar e Silva² (iD, Cecília Ribeiro da Mota e Silva² (iD, Andressa Nathalie Nunes² ${ }^{2}$, Meliza Cristina Pereira de Figueiredo ${ }^{5}$ iD}

\author{
1 Instituto Capixaba de Pesquisa, Assistência Técnica e Extensão Rural, CPDI Norte, Linhares, ES, Brasil. \\ 2 Universidade Federal de Minas Gerais, Escola de Veterinária, Departamento de Zootecnia, Belo Horizonte, MG, Brasil. \\ ${ }^{3}$ Universidade Federal de Viçosa, Campus Florestal, Florestal, MG, Brasil. \\ ${ }^{4}$ Embrapa Gado de Leite, Juiz de Fora, MG, Brasil. \\ ${ }^{5}$ Universidade Federal de Minas Gerais, Departamento de Química, Belo Horizonte, MG, Brasil.
}

\begin{abstract}
This study was conducted to evaluate the effect of substituting Tifton 85 hay (Cynodon sp. cv. Tifton 85) with levels of cocoa (Theobroma cacao) byproduct $(0,8,16$, and $24 \%$, diet dry matter basis) in the diet of 16 Holstein $\times$ Gir heifers with an average body weight of $363.0 \pm 27.7 \mathrm{~kg}$ on their nutrient intake, digestibility, and protein balance. The experimental period was 17 days, and the sample collection period was five days. There was no effect of cocoa byproduct on nutrient intake. However, the byproduct affected the digestibility of dry matter, crude protein, neutral detergent fiber, and acid detergent fiber, all of which decreased as the level of inclusion of the byproduct in the diet was increased. Nitrogen balance was negatively affected by the inclusion of $24 \%$ cocoa byproduct. It is recommended to use cocoa byproduct up to the level of $16 \%$ to replace Tifton 85 grass hay in diets for dairy heifers.
\end{abstract}

Key Words: animal nutrition, digestibility, fiber, intake, Theobroma cacao L.

\section{Introduction}

The cocoa (Theobroma cacao) fruit is a tropical species of great ecological, social, and economic importance for several producing regions that is found spontaneously in the lower stratum of forests. Brazil is the fifth largest producer of cocoa in the world, generating $273.10 \mathrm{t}$ annually, with an average yield of $403.00 \mathrm{~kg} \mathrm{ha}^{-1}$. Bahia is the largest cocoaproducing state in the country, representing approximately $50 \%$ of the total national production (IBGE, 2015). The peel can account for around $80 \%$ of the cocoa fruit; it can be used in the feeding of ruminants as is, in the form of dry flour, or even preserved as silage (Silva Neto et al., 2001).

Nutritionally, the cocoa byproduct is characterized as a highly fibrous feedstuff with a dry matter (DM) content of $150.00 \mathrm{~g} \mathrm{~kg}^{-1}$ and $70.47 \mathrm{~g} \mathrm{~kg}^{-1}$ crude protein (CP), $570.98 \mathrm{~g} \mathrm{~kg}^{-1}$ neutral detergent fiber (NDF), $500.70 \mathrm{~g} \mathrm{~kg}^{-1}$ acid detergent fiber (ADF), and $200.60 \mathrm{~g} \mathrm{~kg}^{-1}$ lignin (dry matter basis) (Valadares Filho et al., 2006).

Received: August 25, 2017

Accepted: May 1, 2018

*Corresponding author: merreg1@yahoo.com.br

Copyright (C) 2018 Sociedade Brasileira de Zootecnia. This is an Open Access article distributed under the terms of the Creative Commons Attribution License (http://creativecommons.org/licenses/by/4.0/), which permits unrestricted use, distribution, and reproduction in any medium, provided the original work is properly cited.
In their review on cocoa byproducts, Marcel et al. (2011) stated that they can be incorporated into ruminant diet as long as they do not exceed the limit of $30 \%$ of the diet because they contain theobromine. The authors went on to state that theobromine is an anti-nutritional factor that can affect the diet digestibility and, consequently, the production performance of animals when ingested in large quantities.

Sustainable use of feed resources has been the primary motivation of research, which has focused on the inclusion of alternative feed sources in animal nutrition, mainly replacing grains in ruminant diets (Pedroso et al., 2009), since the cost of traditional ingredients has limited the efficiency and sustainability of production systems.

The intake of a ruminant animal depends directly on how efficiently the consumed feed is utilized in the rumen environment for energy production. Digestibility, in turn, is directly dependent on the intake level (NRC, 2001) and, consequently, on the variables that affect it. However, factors affecting feed intake are complex and multifactorial, and developing a cohesive theory of intake control in ruminants is still a challenge (Galyean and Gunter, 2016). Interactions among numerous factors such as diet, animal, environment, and management are primarily responsible for the lack of precision in estimates of this parameter (McMenimam et al., 2009). 
There is a high demand of byproducts by farmers, who use them in ruminant feeding; however, scarcity of data - particularly with regard to the nutritional value of cocoa byproducts, nutritional strategies used, and animal performance - has hindered their proper use. Currently, research has been conducted with a view to determining the chemical composition of cocoa byproducts and making recommendations of inclusion levels. One of such byproducts is the cocoa meal, derived from the cocoa bean (Pires et al., 2004; Silva et al., 2005). However, no studies have been carried out to the present date recommending its inclusion level in ruminant diets.

The objective of this study was to evaluate the effect of including levels of cocoa byproduct $(0,8,16$, and $24 \%)$ replacing Tifton 85 grass hay in diets for dairy heifers on the intake, nutrient digestibility, and protein balance of these animals.

\section{Material and Methods}

The study was conducted in Florestal, MG, Brazil $\left(19^{\circ} 53^{\prime} 22^{\prime \prime} \mathrm{S}, 44^{\circ} 25^{\prime} 57^{\prime \prime} \mathrm{W}\right.$, and $753 \mathrm{~m}$ asl), where the average maximum and minimum annual temperatures are 14 and $27{ }^{\circ} \mathrm{C}$, respectively, and annual precipitation is $1434 \mathrm{~mm}$. According to the Köppen classification, the climate of the region is a tropical type of altitude. Experimental procedures were carried out according to the local Ethical Principles of Animal Experimentation (case no. 225/2015).

Sixteen Holstein $\times$ Gir crossbred heifers with an average weight of $363.0 \pm 27.7 \mathrm{~kg}$ were housed individually in $3 \times 3$-m covered pens with concrete floor equipped with feeders and individual troughs made of plastic drums. The diets offered were based on the substitution of Tifton 85 hay (Cynodon sp. cv. Tifton 85) with levels of cocoa (Theobroma cacao) byproduct $(0,8,16$ and $24 \%$, diet dry matter basis), offered in equal meals.

The cocoa byproduct tested in the present study was obtained from CEPLAC (Comissão Executiva de Planejamento da Lavoura Cacaueira; Linhares, ES, Brazil) and producing farms in the region. It was composed of peels, which, after drying in the sun, were stored in drums. Subsequently, the material was ground and added to the diet provided to animals, which was offered in two daily meals (7:00 and 16:00 h). Leftovers were harvested every morning, weighed, and the amount of feed supplied was based on that quantity plus the amount necessary to maintain leftovers at $10 \%$. A mixture of urea:ammonium sulfate was used at a ratio of 9:1. Diets were isonitrogenous and formulated according to the nutritional requirements of dairy cattle (NRC, 2001) (Tables 1 and 2).
The experimental period was 17 days, including 12 days for adaptation of animals to the diets, management, and facilities and a collection period (experimental) of five days. Heifers were weighed at the beginning of the adaptation period. Their intake was measured by weighing the feed supplied and the leftovers. Samples of the feed supplied and the leftovers were collected per treatment and per animal. The feces on the floor of each stall were harvested and sampled per animal and weighed twice

Table 1 - Chemical composition ( $\mathrm{g} \mathrm{kg}^{-1}$ as fed) and gross energy $\left(\mathrm{kcal} \mathrm{kg}^{-1}\right)$ of the experimental diets

\begin{tabular}{lccc}
\hline Nutrient & $\begin{array}{c}\text { Tifton } 85 \text { hay } \\
\text { grass }\end{array}$ & $\begin{array}{c}\text { Corn } \\
\text { meal }\end{array}$ & $\begin{array}{c}\text { Cocoa } \\
\text { byproduct }\end{array}$ \\
\hline Dry matter & 900.30 & 870.00 & 280.90 \\
Mineral matter & 60.00 & 10.60 & 110.70 \\
Crude protein & 60.60 & 90.10 & 80.20 \\
Neutral detergent fiber & 790.40 & 80.30 & 780.60 \\
Acid detergent fiber & 370.70 & 30.50 & 600.60 \\
Total carbohydrates & 850.90 & 850.90 & 770.90 \\
Non-fibrous carbohydrates & 130.10 & 86.35 & 70.60 \\
Lignin & 20.90 & 10.34 & 280.30 \\
NDIN/TN & 400.50 & 50.95 & 680.20 \\
ADIN/TN & 130.30 & 100.90 & 850.60 \\
Ether extract & 10.40 & 30.70 & 20.10 \\
Crude energy & 3939.90 & 4730.80 & 3821.20 \\
IVDMD & 580.00 & 890.10 & 340.00 \\
TDN & 570.70 & 830.50 & 370.70 \\
\hline
\end{tabular}

NDIN - neutral detergent insoluble nitrogen; ADIN - acid detergent insoluble nitrogen; TN - total nitrogen; IVDMD - in vitro dry matter digestibility; TDN - total digestible nutrients, estimated by Capelle et al. (2001).

Table 2 - Proportion of ingredients $\left(\mathrm{g} \mathrm{kg}^{-1}\right)$ and chemical composition of the experimental diets with increasing levels of cocoa byproduct

\begin{tabular}{|c|c|c|c|c|}
\hline \multirow{2}{*}{ Ingredient } & \multicolumn{4}{|c|}{ Experimental diet (\%) } \\
\hline & 0 & 8 & 16 & 24 \\
\hline Tifton 85 hay grass & 790.00 & 710.00 & 620.00 & 530.00 \\
\hline Corn meal & 180.00 & 180.00 & 190.00 & 200.00 \\
\hline Cocoa by-product & 0.00 & 80.00 & 160.00 & 240.00 \\
\hline Urea + ammonium sulfate & 10.00 & 10.00 & 10.00 & 10.00 \\
\hline Vitamin/mineral supplement & 20.00 & 20.00 & 20.00 & 20.00 \\
\hline Total & 1000.00 & 1000.00 & 1000.00 & 1000.00 \\
\hline \multicolumn{5}{|l|}{ Chemical composition of diets } \\
\hline Dry matter & 870.00 & 820.10 & 770.20 & 722.20 \\
\hline Mineral matter & 50.00 & 54.90 & 59.10 & 63.20 \\
\hline Crude protein & 97.00 & 98.00 & 100.00 & 101.00 \\
\hline Neutral detergent fiber & 642.40 & 641.50 & 633.90 & 626.10 \\
\hline Acid detergent fiber & 320.10 & 336.80 & 349.80 & 362.80 \\
\hline Total carbohydrates & 834.10 & 827.60 & 821.20 & 814.70 \\
\hline Non-fibrous carbohydrates & 261.00 & 256.90 & 259.30 & 261.70 \\
\hline Lignin & 25.20 & 45.80 & 65.80 & 86.00 \\
\hline Ether extract & 15.70 & 18.40 & 19.20 & 20.00 \\
\hline Crude energy ( $\mathrm{kcal} \mathrm{kg}^{-1}$ ) & 3955.70 & 3925.60 & 3885.10 & 3852.60 \\
\hline TDN & 657.20 & 612.40 & 641.30 & 572.30 \\
\hline NDIN & 3.60 & 3.90 & 4.30 & 4.60 \\
\hline NDIN/TN & 333.40 & 355.30 & 373.80 & 392.20 \\
\hline ADIN & 1.90 & 2.70 & 3.50 & 4.30 \\
\hline ADIN/TN & 158.10 & 216.00 & 275.40 & 334.90 \\
\hline
\end{tabular}

TDN - total digestible nutrients; NDIN - neutral detergent insoluble nitrogen; ADIN - acid detergent insoluble nitrogen; $\mathrm{TN}$ - total nitrogen. 
daily. Approximately $10 \%$ of each sample were placed in plastic bags that were kept in a freezer at $-10{ }^{\circ} \mathrm{C}$ for later laboratory analysis.

Spot urine samples were harvested on the last day of the collection period, $4 \mathrm{~h}$ after the feed supply, during spontaneous urination, and then frozen at $-20{ }^{\circ} \mathrm{C}$ for subsequent analysis of creatinine. The urinary volume was estimated from the average daily excretion of creatinine in $\mathrm{mg} \mathrm{kg}{ }^{-1}$ and body weight (BW) day ${ }^{-1}$ and the creatinine concentration $\left(\mathrm{mg} \mathrm{L}^{-1}\right)$ in the spot urine sample (Fujihara et al., 1987). The creatinine concentration in urine was estimated using a commercial kit (Labtest ${ }^{\circledR}$ Diagnóstico S/A; Lagoa Santa, MG, Brazil).

Samples of the feed supplied daily, leftovers, and feces were thawed, dried in a forced-air oven at $55{ }^{\circ} \mathrm{C}$ for $72 \mathrm{~h}$, ground through a knife mill with a 1-mm mesh sieve, and stored for laboratory analyses. These samples were analyzed for DM, CP, ether extract (EE), and total ash according to Detmann et al. (2012). Neutral detergent fiber, ADF, neutral detergent insoluble nitrogen (NDIN), acid detergent insoluble nitrogen (ADIN), and lignin contents were determined using the methodology of Van Soest et al. (1991). Total carbohydrates (TC) estimates were obtained using the equation proposed by Sniffen et al. (1992). To estimate the non-fibrous carbohydrates (NFC), we used the equation proposed by Hall (2000) for urea-containing feeds.

To calculate the total digestible nutrients (TDN) of the diets, we employed the equation proposed by Weiss (1999). The TDN were estimated separately, as proposed by equations of Capelle et al. (2001), for roughages (TDN = $\left.\left(10.43+0.8019^{*} \mathrm{ADDM}\right)\right)\left(\mathrm{r}^{2}=0.89 ; \mathrm{P}<0.01\right)$ and concentrates $(\mathrm{TDN}=(9.6134+0.8294 * \mathrm{ADDM}))\left(\mathrm{r}^{2}=0.98 ; \mathrm{P}<0.01\right)$, in which ADDM = apparent digestibility of DM.

Digestibility and nutrient balance were determined using the total collection method. The apparent digestibility (AD) of DM, CP, EE, NDF, ADF, and TC was calculated from the difference between ingested nutrients and nutrients excreted in the feces, as a function of nutrient intake (Kozloski et al., 2009):

$$
\mathrm{AD}(\%)=\frac{[(\text { nutrient intake }- \text { nutrient excreted in feces })]}{\text { nutrient intake }} \times 100
$$

The gross energy in the samples of feed supplied, leftovers, feces, and urine was obtained using a PARR 1281 adiabatic calorimeter. The nitrogen balance was also determined after obtaining the absorbed nitrogen in grams per day $\left(\mathrm{g} \mathrm{day}^{-1}\right)$. To determine the amount of nitrogen absorbed, $\mathrm{N}$ intake, $\mathrm{N}$ in feces, and $\mathrm{N}$ in urine were quantified as shown below:

Retained $\mathrm{N}\left(\mathrm{g} \mathrm{day}^{-1}\right)=\mathrm{N}$ intake $-(\mathrm{N}$ feces $+\mathrm{N}$ urine $)$; and
Absorbed $\mathrm{N}\left(\mathrm{g}\right.$ day $\left.^{-1}\right)=(\mathrm{N}$ intake $-\mathrm{N}$ feces $)$.

The animals were distributed into four treatments in a completely randomized design with four replicates per treatment. Data were subjected to analysis of variance and regression, according to the inclusion of cocoa byproduct in the diets $(0,8,16$, and 24\%), using SAS (Statistical Analysis, System, version 6.4) software. The mathematical model used was:

$$
\mathrm{Y} i j=\beta 0+\beta 1 x i+\beta 2 x i^{2}+\alpha j+\varepsilon i j k,
$$

in which $Y_{i j}=$ dependent variables, $\beta$ 's $=$ regression coefficients, $x i=$ inclusion levels, $\alpha j=$ deviations from the regression, and $\varepsilon i j k=$ residual random error.

The most adequate model for each variable was selected based on the significance of the linear and quadratic coefficients, using the level of 0.05 significance. Means were compared by the Student-Newman-Keuls test $(\mathrm{P}<0.05)$.

\section{Results}

There was no effect of cocoa byproduct inclusion on the analyzed variables, which were expressed in $\mathrm{kg} \mathrm{heifer}^{-1}$ day $^{-1}$, as a percentage of live weight $(\% \mathrm{BW})$, or as a function of metabolic weight $\left(\mathrm{g} \mathrm{kg}^{-0.75}\right)$. Average $\mathrm{DM}$ intake values ranged from 7.35 to $8.41 \mathrm{~kg} \mathrm{day}^{-1}$, and the same behavior was observed when expressed relative to body weight (20.50 to $23.10 \mathrm{~g} \mathrm{~kg}^{-1}$ day $^{-1} \mathrm{BW}$ ) and metabolic weight (89.21 to $100.78 \mathrm{~g} \mathrm{~kg}^{-0.75}$ ) (Table 3).

The cocoa byproduct is characterized as a highly fibrous feedstuff with high levels of NDF, ADF, and lignin (780.60, 600.60, and $280.30 \mathrm{~g} \mathrm{~kg}^{-1} \mathrm{DM}$, respectively) (Table 1).

Diets with $24 \%$ inclusion of cocoa byproduct had a quadratic effect $(\mathrm{P}<0.05)$ on the digestibility of $\mathrm{DM}, \mathrm{CP}$, NDF, and ADF (Table 4). The apparent digestibility of the fibrous fractions (NDF and ADF), which ranged from 552.50 to $377.50 \mathrm{~g} \mathrm{~kg}^{-1}$ and from 479.70 to 297.50 , respectively, was influenced $(\mathrm{P}<0.05)$ by the inclusion of cocoa byproduct in the diets.

Inclusion of cocoa byproduct had a quadratic effect $(\mathrm{P}<0.05)$ on fecal nitrogen, absorbed nitrogen, nitrogen balance, and nitrogen use efficiency (retained nitrogen/ ingested nitrogen) (Table 5).

The protein composition of the diets (Table 2) (CP and ADIN) reveals available protein values of 85.12 , $81.12,78.12$, and $73.12 \mathrm{~g} \mathrm{~kg}^{-1}(0,8,16$, and $24 \%$ of inclusion, respectively). The respective calculated values recommended by the NRC (2001) are 85.40, 79.60, 83.30, and $74.40 \mathrm{~g} \mathrm{~kg}^{-1}$ for diets with increasing levels of cocoa byproduct. 
Table 3 - Average daily intake $\left(\mathrm{kg} \mathrm{day}^{-1}\right)$, percentage of body weight $\left(\mathrm{g} \mathrm{kg}^{-1} \mathrm{BW}\right)$, metabolic size unit $\left(\mathrm{kg} \mathrm{kg}^{-0.75}\right)$, coefficient of variation (CV; \%), standard error of mean (SEM), and P-value as a function of byproduct cocoa inclusion levels supplied to dairy heifers

\begin{tabular}{|c|c|c|c|c|c|c|c|}
\hline \multirow{2}{*}{ Item } & \multicolumn{4}{|c|}{ Cocoa byproduct (\%) } & \multirow{2}{*}{$\mathrm{CV}$} & \multirow{2}{*}{ SEM } & \multirow{2}{*}{ P-value } \\
\hline & 0 & 8 & 16 & 24 & & & \\
\hline \multicolumn{8}{|c|}{ Intake $\left(\mathrm{kg} \mathrm{day}^{-1}\right)$} \\
\hline DMI & 7.35 & 8.41 & 8.12 & 7.65 & 15.67 & 1.6 & 0.6470 \\
\hline OMI & 6.97 & 7.96 & 7.67 & 7.20 & 14.72 & 1.5 & 0.6446 \\
\hline CPI & 0.75 & 0.83 & 0.81 & 0.79 & 11.24 & 0.1 & 0.6962 \\
\hline EEI & 0.14 & 0.16 & 0.16 & 0.16 & 15.80 & 0.3 & 0.4952 \\
\hline NDFI & 4.84 & 5.49 & 5.29 & 4.87 & 14.92 & 1.0 & 0.6042 \\
\hline ADFI & 2.40 & 2.80 & 2.78 & 2.65 & 15.33 & 0.5 & 0.5551 \\
\hline NFCI & 1.47 & 1.71 & 1.64 & 1.62 & 14.16 & 0.4 & 0.5150 \\
\hline TCHOI & 6.31 & 7.20 & 6.93 & 6.49 & 16.01 & 1.4 & 0.7564 \\
\hline \multicolumn{8}{|c|}{ Intake ( $\left.\mathrm{g} \mathrm{kg}^{-1} \mathrm{BW}\right)$} \\
\hline DMI & 20.50 & 23.10 & 22.10 & 21.00 & 15.67 & 0.8 & 0.6815 \\
\hline OMI & 19.50 & 21.90 & 20.90 & 19.70 & 14.72 & 0.7 & 0.6723 \\
\hline CPI & 2.10 & 2.30 & 2.20 & 2.20 & 11.24 & 0.1 & 0.8159 \\
\hline NDFI & 13.50 & 15.10 & 14.40 & 13.30 & 14.92 & 0.5 & 0.6259 \\
\hline ADFI & 6.70 & 7.70 & 7.60 & 7.30 & 15.33 & 0.3 & 0.6198 \\
\hline TCHOI & 18.50 & 19.70 & 17.50 & 17.40 & 16.01 & 0.7 & 0.6603 \\
\hline \multicolumn{8}{|c|}{ Intake $\left(\mathrm{kg} \mathrm{kg}^{-0.75}\right)$} \\
\hline DMI & 89.21 & 100.78 & 96.87 & 91.67 & 14.60 & 21.2 & 0.8831 \\
\hline OMI & 84.60 & 95.41 & 91.45 & 86.29 & 14.54 & 31.1 & 0.6619 \\
\hline CPI & 9.10 & 9.88 & 9.67 & 9.46 & 10.99 & 2.0 & 0.6448 \\
\hline NDFI & 58.73 & 65.86 & 63.07 & 58.28 & 14.57 & 21.6 & 0.0988 \\
\hline ADFI & 29.15 & 33.53 & 33.20 & 31.79 & 15.01 & 11.6 & 0.5738 \\
\hline TCHOI & 80.20 & 85.99 & 76.61 & 75.89 & 16.11 & 30.5 & 0.6783 \\
\hline
\end{tabular}

BW - body weight; DMI - dry matter intake; OMI - organic matter intake; CPI - crude protein; EEI - ether extract intake; NDFI - neutral detergent fiber intake; ADFI acid detergent fiber intake; NFCI - non-fibrous carbohydrates intake; TCHOI - total carbohydrates intake.

\section{Discussion}

Little information is available on the cocoa byproduct and its use in ruminant diets. According to Oliveira et al. (2013), the inclusion of byproducts in ruminant feeding is beneficial, because in addition to lowering feed costs, they usually maintain the productivity and quality of products as long as the diets are balanced to meet the nutritional requirements of animals. The analysis of the cocoa byproduct showed that the ingredient is highly fibrous, which may lead to decreased intake and digestibility of nutrients. Exclusive inclusion thereof should be evaluated, since the NDF concentration in the feed is negatively correlated with its energy content. In the present study, intake was not changed by the inclusion of cocoa byproduct in the diets. It is noteworthy that the experimental animals, which were in their growth stage, accepted the ingredient well. As described in the NRC (2001), the estimated DM intake for this animal category is $7.90 \mathrm{~kg} \mathrm{DM} \mathrm{day}^{-1}$, similar to the value found in this study.

According to Van Soest (1994), byproducts usually do not contribute with protein, and excess lignin can make the little existing protein unavailable and limit the intake of dry matter. It is important to point out that control diet also did not reach the ideal set by the NRC; therefore, the reported $\mathrm{CP}$ intake may be related to the diet rather than the

Table 4 - Regression equations, coefficients of variation $(\mathrm{CV} ; \%)$ and determination $\left(\mathrm{r}^{2}\right)$ for the digestibility $\left(\mathrm{g} \mathrm{kg}^{-1}\right)$ of nutrients in the different treatments

\begin{tabular}{|c|c|c|c|c|c|c|c|}
\hline \multirow{2}{*}{ Item } & \multicolumn{4}{|c|}{ Cocoa byproduct (\%) } & \multirow{2}{*}{ Equation } & \multirow{2}{*}{$\mathrm{CV}$} & \multirow{2}{*}{$\mathrm{r}^{2}$} \\
\hline & 0 & 8 & 16 & 24 & & & \\
\hline DMd & $585.30 \mathrm{a}$ & $560.90 \mathrm{a}$ & $617.30 \mathrm{a}$ & $471.00 \mathrm{~b}$ & $\hat{Y}=478.0+123.5 X-30.4 X^{2}$ & 6.45 & 0.66 \\
\hline $\mathrm{CPd}$ & $665.80 \mathrm{a}$ & $600.50 \mathrm{ab}$ & $650.90 \mathrm{a}$ & $507.40 \mathrm{~b}$ & $\hat{\mathrm{Y}}=614.4+55.4 \mathrm{X}-19.6 \mathrm{X}^{2}$ & 11.77 & 0.68 \\
\hline EEd & 570.60 & 633.00 & 655.80 & 673.50 & $\hat{\mathrm{Y}}=633.23$ & 3.46 & 0.90 \\
\hline NDFd & $552.50 \mathrm{a}$ & $495.00 \mathrm{a}$ & $490.30 \mathrm{a}$ & $377.50 \mathrm{~b}$ & $\hat{\mathrm{Y}}=540.6+16.34 \mathrm{X}-13.7 \mathrm{X}^{2}$ & 9.73 & 0.92 \\
\hline ADFd & $479.70 \mathrm{a}$ & $400.20 \mathrm{a}$ & $412.60 \mathrm{a}$ & $297.50 b$ & $\hat{\mathrm{Y}}=481.3-3.6 \mathrm{X}-9.8 \mathrm{X}^{2}$ & 10.51 & 0.85 \\
\hline TCHOd & 632.70 & 590.20 & 609.60 & 521.60 & $\hat{\mathrm{Y}}=588.53$ & 5.93 & 0.77 \\
\hline
\end{tabular}

DMd - dry matter digestibility; CPd - crude protein digestibility; EEd - ether extract digestibility; NDFd - neutral detergent fiber digestibility; ADFd - acid detergent fiber digestibility; TCHOd - total fibrous carbohydrates digestibility.

Means with different letters in the rows differ statistically by SNK test $(\mathrm{P}<0.05)$

Table 5 - Parameters related to nitrogen balance (g/day), coefficients of variation $(\mathrm{CV} ; \%)$, determination $\left(\mathrm{r}^{2}\right)$, and regression equations of heifers fed increasing levels of cocoa byproduct

\begin{tabular}{|c|c|c|c|c|c|c|c|}
\hline \multirow{2}{*}{ Item } & \multicolumn{4}{|c|}{ Cocoa byproduct $(\%)$} & \multirow{2}{*}{ Equation } & \multirow{2}{*}{$\mathrm{CV}$} & \multirow{2}{*}{$\mathrm{r}^{2}$} \\
\hline & 0 & 8 & 16 & 24 & & & \\
\hline Nitrogen intake & 119.73 & 131.90 & 129.64 & 126.20 & $\hat{\mathrm{Y}}=126.87$ & 11.94 & - \\
\hline Fecal nitrogen & $40.47 \mathrm{~b}$ & $52.85 \mathrm{ab}$ & $44.72 \mathrm{ab}$ & $61.22 \mathrm{a}$ & $\hat{Y}=41.43+0.263 X+1.03 X^{2}$ & 18.83 & 0.59 \\
\hline Absorbed nitrogen & $79.26 \mathrm{a}$ & $79.04 \mathrm{a}$ & $84.92 \mathrm{a}$ & $64.98 b$ & $\hat{\mathrm{Y}}=61.61+21.00 \mathrm{X}-4.95 \mathrm{X}^{2}$ & 7.30 & 0.77 \\
\hline Urinary nitrogen & 20.20 & 21.61 & 19.10 & 18.57 & $\hat{\mathrm{Y}}=19.87$ & 18.97 & - \\
\hline Nitrogen balance & $59.06 \mathrm{a}$ & $57.43 \mathrm{a}$ & $65.82 \mathrm{a}$ & $46.41 b$ & $\hat{Y}=42.74+18.81 X-4.34 X^{2}$ & 9.12 & 0.63 \\
\hline $\mathrm{AN} / \mathrm{NI}(\%)$ & $49.30 \mathrm{a}$ & $43.50 \mathrm{a}$ & $50.80 \mathrm{a}$ & $36.70 \mathrm{~b}$ & $\hat{\mathrm{Y}}=43.33+6.62 \mathrm{X}-1.96 \mathrm{X}^{2}$ & 10.30 & 0.52 \\
\hline
\end{tabular}

Means with different letters in the rows differ statistically by SNK test $(\mathrm{P}<0.05)$.

$\mathrm{AN}$ - absorbed nitrogen; NI - nitrogen intake. 
replacement of Tifton 85 grass hay by cocoa byproduct. The lack of effects of cocoa byproduct on DM intake and the fact that the diets were isonitrogenous support this finding.

Mean values for the intakes of NDF, ADF, and TC did not differ significantly $(\mathrm{P}>0.05)$ with the increasing cocoa byproduct levels in the diets, following the response shown by DM intake: $5.12,2.66$, and $6.73 \mathrm{~kg} \mathrm{day}^{-1}$, or 61.49 , 31.92 , and $79.67 \mathrm{~g} \mathrm{~kg}^{-0.75}$, respectively. The absence of effects on the intake of fibrous fractions with increasing addition of cocoa byproduct to the diets was probably a result of the nutrient composition of the treatments, which were balanced so that the diets would remain isofibrous.

Neutral detergent fiber intake as a function of body weight ranged from 13.30 to $15.10 \mathrm{~g} \mathrm{~kg}^{-1}$ day $^{-1}$. According to Mertens (1992), an NDF intake above $12.00 \mathrm{~g} \mathrm{~kg}^{-1}$ day $^{-1}$ would be one of the main physical regulatory mechanisms of DM intake. However, other aspects influence the animal intake responses, e.g., particle size, frequency and effectiveness of chews, fragility of the particles, proportions of indigestible NDF, and the potentially digestible fermentation rate of NDF (Allen, 1996). Nevertheless, there was no reduction of DM intake, probably because of the similar levels of NDF present in the experimental diets, which may have maintained the nutrient intakes similar across the treatments. It is important that the NDF content does not limit intake so that animals be able to consume sufficient amounts of DM that will meet their energy requirements rather than negatively influence their production (Moreira et al., 2014; Azevedo et al., 2013; Correia et al., 2012).

This result can be a convincing reason for the inclusion of cocoa byproduct in the diet of dairy heifers, since intake is fundamental to performance. Additionally, this feedstuff can be used by virtue of its good acceptance and palatability. Millen et al. (2009) described that $80 \%$ of Brazilian nutritionists use some byproduct in their formulations for animal feeding to reduce feed costs. Therefore, the cocoa byproduct may represent a new alternative, depending on its regional availability.

In terms of nutrient digestibility, the cocoa byproduct showed a quadratic behavior for the digestibility of DM, $\mathrm{CP}, \mathrm{NDF}$, and ADF. These results reflect the negative influence of the fibrous fractions, lignin, and possibly tannin and theobromine contents present in cocoa byproduct, as observed in the in vitro dry matter digestibility values presented here.

As pointed out by Marcel et al. (2011) in their review on cocoa byproducts in animal feeding, the digestibility of $\mathrm{DM}$ and CP decreases with increasing levels of inclusion of these byproducts in ruminant diets, because their inclusion elevates the dietary concentration of NDF and ADF, compromising the access of digestive enzymes from the small intestine to the feed substrate.

Lousada Junior et al. (2006) compared the DM digestibility (DMd) coefficients of pineapple, acerola (Malpighia emarginata), guava, passion fruit, and melon byproducts provided separately to sheep and found lower digestibility for acerola (22.79\%) and guava (30.84\%) byproducts compared with the others. These low DMd values in the diets with inclusion of cocoa byproduct show that the use of this alternative feed should be considered with caution and is recommended only for situations with a better cost:benefit ratio or even lacking traditional feedstuffs.

The presence of theobromine in cocoa, a methylxanthinelike caffeine, could be believed to affect the rumen metabolism, influencing DMd in some way. However, although it was not measured in this study, theobromine is assumed to not be toxic to heifers. The explanation for this is that, as described by Adamafio (2013), when under the toxic effect of theobromine, ruminants display reactions of excitability, reduced heart frequency, and digestive disorders. No behavioral alterations were observed in the animals during the experimental period. Thus, in the current study, theobromine was not an antinutritional factor.

The NDIN and ADIN contents of cocoa byproduct negatively affected the $\mathrm{CP}$ digestibility (CPd), which can be proven by the reduced digestibility of ADF with the highest proportion of cocoa in the diet. According to Van Soest (1994), the ADIN contents of a feedstuff interfere with CPd. Considering the ADIN contents in this experiment (Table 2), it appears that the inclusion of cocoa byproduct raised the ADIN levels, with a tendency to reduce CPd at the maximum level of $24 \%$. The CP digestibility at the highest level of inclusion in this study led to better results $\left(507.40 \mathrm{~g} \mathrm{~kg}^{-1}\right)$ than that found by Rogério (2005), who worked with guava byproduct $\left(390.50 \mathrm{~g} \mathrm{~kg}^{-1}\right)$. According to that author, the high content of $\operatorname{ADIN}\left(210.00 \mathrm{~g} \mathrm{~kg}^{-1} /\right.$ total $\left.\mathrm{N}\right)$ and the lower CP content of the byproduct $\left(80.50 \mathrm{~g} \mathrm{~kg}^{-1}\right)$ contributed to this result. A similar fact may have occurred in the present study, in which the ADIN:total nitrogen ratio ranged from 158.10 to $334.90 \mathrm{~g} \mathrm{~kg}^{-1}$ and the CP content of cocoa byproduct was $80.20 \mathrm{~g} \mathrm{~kg}^{-1}$ (Tables 2 and 1, respectively).

Regarding the digestibility of the fibrous fractions of the evaluated diets (ADF and NDF), NDF had a large participation in the total composition of the diets. The reduction of digestibility values of these fractions with the inclusion of the highest level of the cocoa byproduct may 
be related to the higher lignin content of this diet, which was proven in the chemical composition of the byproduct (Tables 1 and 2).

Azevêdo et al. (2011) considered cocoa husks a lowenergy (TDN $588.30 \mathrm{~g} \mathrm{~kg}^{-1} \mathrm{DM}$ ) byproduct with a high cell wall content, which is associated with its lignin concentration (185.40 $\left.\mathrm{g} \mathrm{kg}^{-1} \mathrm{DM}\right)$. In the present study, the 370.70 and $280.30 \mathrm{~g} \mathrm{~kg}^{-1} \mathrm{DM}$ values found for TDN and lignin, respectively, are attributed to the reduced digestibility of the fibrous fractions in the evaluated diets (ADFd and NDFd) with the inclusion of the highest level of cocoa byproduct (Tables 1 and 2). Thus, in terms of digestibility of the fibrous fractions of the evaluated diets, NDF had a high participation in their total composition, generating a ruminal environment with less energy available for microbial fermentation and with a higher participation of indigestible fraction due to the lignin present in large quantities in the cocoa byproduct.

Forbes (1995) stated that digestibility is the product of ruminal retention time and the degradation characteristics of the feed under study. The ADF fraction is composed of cellulose and lignin, and the digestibility of a feedstuff is related to the quantity of this fiber, since lignin represents a greater proportion of ADF in the byproduct. Rogério (2005) found higher results evaluating the inclusion of increasing levels of acerola byproduct in the diet of sheep $(0,12,29$, and $43 \%$ ), reporting NDF and ADF digestibility values of 590.00-470.00 and 460.00-360.00 $\mathrm{g} \mathrm{kg}^{-1}$, respectively.

Our findings corroborate those published by Van Soest (1994), who stated that, when no protein and volatile fatty acids are available in the rumen simultaneously, the efficiency of microbial protein production decreases and the fiber degradation is consequently compromised, causing rumen fill, which explains the lower fiber digestibility.

Nitrogen balance was affected by the inclusion of cocoa byproduct in the diets. This result may be due to the reduced amount of fermentable carbohydrates and high lignin content present in the diet, because, although the nitrogen content of the diets was similar, its availability differed. This is because the NDIN and ADIN contents of cocoa byproduct and Tifton 85 grass hay may have negatively influenced the synchronism between protein and ruminal energy. The TDN values presented for the diet with highest inclusion of cocoa byproduct were lower, contributing to this fact (Table 2). In the same way, the solubility of the dietary nitrogen source used in the present study (urea) possibly contributed to this finding.

The efficiency of energy and protein utilization in ruminant diets depends on the relationship between these two. Thus, it is important to consider the rumen-degradable: undegradable protein ratio, amino acid and energy profile available for the animal metabolism, and microbial fermentation in the formulation of ruminant diets. The literature recommends that microbial efficiency be estimated based on the degradable protein:dietary energy ratio, which should be $130.00 \mathrm{~g} \mathrm{~kg}^{-1}$ TDN (NRC, 2001). Based on this, it can be determined that, in this study, the diets with the highest levels of cocoa byproduct addition (16\% and 24\%) led to lower rumen-available protein values.

Nevertheless, DM intake was not affected by the inclusion of cocoa byproduct, presumably due to the endogenous recycling of $\mathrm{N}$.

\section{Conclusions}

Cocoa byproduct affects the digestibility of diets of dairy heifers and their nitrogen balance. Thus, the use of $16 \%$ cocoa byproduct replacing Tifton 85 grass hay in the diet is recommended if it is readily available and economically viable.

\section{Acknowledgments}

The authors would like to thank the Instituto Capixaba de Pesquisa, Assistência Técnica e Extensão Rural (INCAPER/ES) and Central de Ensino e Desenvolvimento Agrário de Florestal (CEDAF UFV/MG), for the support in the development of the experiment; and Comissão Executiva do Plano da Lavoura Cacaueira (CEPLAC/ES) and producer Emir de Macedo Gomes Filho, for providing the cocoa byproduct. This study is part of the thesis of the first author.

\section{References}

Adamafio, N. A. 2013. Theobromine toxicity and remediation of cocoa by-products: An overview. Journal of Biological Sciences 13:570-576. https://doi.org/10.3923/jbs.2013.570.576

Allen, M. S. 1996. Physical constraints on voluntary intake of forages by ruminants. Journal of Animal Science 74:3063-3075. https://doi.org/10.2527/1996.74123063x

Azevêdo, J. A. G.; Valadares Filho, S. C.; Pina, D. S.; Valadares, R. F. D.; Detmann, E.; Paulino, M. F.; Diniz, L. L. and Fernandes, H. J. 2011. Consumo, digestibilidade total, produção de proteína microbiana e balanço de nitrogênio em dietas para ruminantes de subprodutos. Arquivo Brasileiro de Medicina Veterinária e Zootecnia 63:114-123. https://doi.org/10.1590/S0102-09352011000100018

Azevedo, R. A.; Bicalho, F. L.; Araújo, F.; Ribeiro Jr, C. S.; Santos, A. C. R.; Jayme, D. G. and Geraseev, L. C. 2013. Technical and economic analysis of different levels of macauba cake in diets for dairy cows. Archivos de Zootecnia 62:147-150. https://doi.org/10.4321/S000405922013000100016 
Cappelle, E. R.; Valadares Filho, S. C. V.; Silva, J. F. C. and Cecon, P. R. 2001. Estimativas do valor energético a partir de características químicas e bromatológicas dos alimentos. Revista Brasileira de Zootecnia 30:1837-1856. https://doi.org/10.1590/ S1516-35982001000700022

Correia, B. R.; Oliveira, R. L.; Jaeger, S. M. P. L.; Bagaldo, A. R.; Carvalho, G. G. P.; Oliveira, G. J. C.; Lima, F. H. S. and Oliveira, P. A. 2012. Comportamento ingestivo e parâmetros fisiológicos de novilhos alimentados com tortas do biodiesel. Archivos de Zootecnia 61:79-89. https://doi.org/10.4321/S0004-05922012000100009

Detmann, E.; Souza, M. A.; Valadares Filho, S. C.; Queiroz, A. C.; Berchielli, T. T.; Saliba, E. O. S.; Cabral, L. S.; Pina, D. S.; Ladeira, M. M. and Azevedo, J. A. G. 2012. Métodos para análises de alimentos - INCT - Ciência Animal. Suprema, Visconde do Rio Branco.

Forbes, J. M. 1995. Voluntary food intake and diet selection in farm animals. CAB International, Wallingford.

Fujihara, T.; Ørskov, E. R.; Reeds, P. J. and Kyle, D. J. 1987. The effect of protein infusion on urinary excretion of purine derivatives in ruminants nourished by intragastric nutrition. Journal of Agricultural Science 109:7-12. https://doi.org/10.1017/S0021859600080916

Galyean, M. L. and Gunter, S. A. 2016. Predicting forage intake in extensive grazing systems. Journal of Animal Science 94(S6):26-43. https://doi.org/10.2527/jas.2016-0523

Hall, M. B. 2000. Calculation of non-structural carbohydrate content of feeds that contain non-protein nitrogen. Bulletin 339. University of Florida, Gainesville. p.A-25.

IBGE - Instituto Brasileiro de Geografia e Estatística. 2015. Produção Agrícola Municipal: culturas temporárias e permanentes, Rio de Janeiro, 42:1-57.

Kozloski, G. V.; Mesquita, F. R.; Alves, T. P.; Castagnino, D. S.; Stefanello, C. M. and Sanchez, L. M. B. 2009. Avaliação do uso de frações indigestíveis do alimento como indicadores internos de digestibilidade em ovinos. Revista Brasileira de Zootecnia 38:1819-1823. https://doi.org/10.1590/S1516-35982009000900026

Lousada Junior, J. E.; Costa, J. M. C.; Neiva, J. N. M. and Rodriguez, N. M. 2006. Caracterização físicoquímica de subprodutos obtidos do processamento de frutas tropicais visando seu aproveitamento na alimentação animal. Revista Ciência Agronômica 37:70-76.

Marcel, B. K. G.; André, K. B.; Dally, T. and Séraphin, K. C. 2011. Waste and by-products of cocoa in breeding: Research synthesis. International Journal of Agronomy and Agricultural Research 1:9-19.

McMeniman, J. P.; Defoor, P. J. and Galyean, M. L. 2009. Evaluation of the National Research Council (1996) dry matter intake prediction equations and relationships between intake and performance by feedlot cattle. Journal of Animal Science 87:1138-1146.

Mertens, D. R. 1992. Análise da fibra e sua utilização na avaliação de alimentos e formulações de rações. p.188. In: Anais do Simpósio Internacional de Ruminantes. Sociedade Brasileira de Zootecnia, Lavras.
Millen, D. D.; Pacheco, R. D. L.; Arrigoni, M. D. B.; Galyean, M. L. and Vasconcelos, J. T. 2009. A snapshot of management practices and nutritional recommendations used by feed lot nutritionists in Brazil. Journal of Animal Science 87:3427-3439.

Moreira, M. N.; Silva, A. M. A.; Carneiro, H.; Bezerra, L. R.; Morais, R. K. O. and Medeiros, F. F. 2014. In vitro degradability and total gas production of biodiesel chain byproducts used as a replacement for cane sugar feed. Acta Scientiarum. Animal Sciences 36:399-403. https://doi.org/10.4025/actascianimsci.v36i4.23950

NRC - National Research Council. 2001. Nutrient requirements of dairy cattle. 7th. ed. National Research Council, National Academy of Sciences, Washington, DC.

Oliveira, R. L.; Leão, A. G.; Abreu, L. L.; Teixeira, S. and Silva, T. M. 2013. Alimentos alternativos na dieta de ruminantes. Revista Científica de Produção Animal 15:141-160.

Pedroso, A. M.; Santos, F. A. P. and Bittar, C. M. M. 2009. Substituição do milho em grão por farelo de glúten de milho na ração de vacas em lactação em confinamento. Revista Brasileira de Zootecnia 38:1614-1619. https://doi.org/10.1590/S151635982009000800028

Pires, A. J. V.; Carvalho Jr, J. N.; Silva, F. F.; Veloso, C. M.; Souza, A. L.; Oliveira, T. N.; Santos, C. L.; Carvalho, G. G. P. and Bernardino, F. S. 2004. Farelo de cacau (Theobroma cacao) na alimentação de ovinos. Revista Ceres 26:33-46.

Rogério, M. C. P. 2005. Valor nutritivo de subprodutos de frutas para ovinos. Tese (D.Sc.). Universidade Federal de Minas Gerais, Belo Horizonte, MG, Brasil.

Silva, H. G. O.; Pires, A. J. V.; Silva, F. F.; Veloso, C. M.; Carvalho, G. G. P.; Cezário, A. S. and Santos, C. C. 2005. Farelo de cacau (Theobroma cacao L.) e torta de dendê (Elaeis guineensis, Jacq) na alimentação de cabras em lactação: Consumo e produção de leite. Revista Brasileira de Zootecnia 34:1786-1794. https://doi.org/ 10.1590/S1516-35982005000500040

Silva Neto, P. J.; Matos, P. G. G.; Martins, A. C. S. and Silva, A. P. 2001. Sistema de produção de cacau para Amazonia Brasileira. Available at: <http://www.ceplacpa.gov.br/site/wp-content/ uploads $/ 2009 / 12 /$ sistema $\% 20$ producao $\% 20$ cacau.pdf $>$. Accessed on: Jan, 10, 2017.

Sniffen, C. J.; O'Connor, J. D.; Van Soest, P. J; Fox, D. G. and Russell, J. B. 1992. A net carbohydrate and protein system for evaluating cattle diets: II. Carbohydrate and protein availability. Journal of Animal Science 70:3562-3577. https://doi.org/10.2527/1992.70113562x

Valadares Filho, S. C.; Magalhães, K. A.; Rocha Júnior, V. R. and Capelle, E. R. 2006. Tabelas brasileiras de composição de alimentos para bovinos: CQBAL 2.0. 2.ed. DZO/UFV, Viçosa, MG.

Van Soest, P. J.; Robertson, J. B. and Lewis, B. A. 1991. Methods for dietary fiber, neutral detergent fiber, and nonstarch polysaccharides in relation to animal nutrition. Journal of Dairy Science 74:35833597. https://doi.org/10.3168/jds.S0022-0302(91)78551-2

Van Soest, P. J. 1994. Nutritional ecology of the ruminant. 2nd ed. Cornell University Press, Ithaca, NY.

Weiss, W. P. 1999. Energy prediction equations for ruminant feeds. p.176-185. In: Proceedings of the 61th Cornell Nutrition Conference for Feed Manufacturers. Cornell University, Ithaca. 